\title{
БІОІНДИКАЦІЇ СТАНУ ЕДАФОТОПУ ЗА ПОКАЗНИКАМИ АКУМУЛЯЦІї ВАЖКИХ МЕТАЛІВ ВЕГЕТАЦЙНИМИ ОРГАНАМИ (на прикладі Taraxacum officinale Wigg.)
}

\author{
I. О. Комарова* \\ Криворізъкий державний педагогічний університет, \\ м. Кривий Ріг, Україна
}

\begin{abstract}
Анотація. Можливість використання розповсюджених видів урбанофлори в біоіндикації для оцінювання рівня забруднення промислових агломерацій актуалізує наші дослідження. Мета роботи - проаналізувати вміст важких металів $(\mathrm{Zn}, \mathrm{Pb}, \mathrm{Cu}, \mathrm{Ni}, \mathrm{Cd})$ у зразках грунту та рослинного матеріалу Taraxacum officinale Wigg Криворізького гірничо-металургійному регіону та можливість використовування з'ясованих закономірностей для здійснення біоіндикації довкілля цього регіону. Пробні ділянки закладалися в трьох адміністративних районах м. Кривий Ріг з різним рівнем надходження викидів від стаціонарних джерел забруднення в атмосферне повітря. За загальноприйнятими методиками здійснювали: відбір проб грунту $(0-10$ см), коренів рослин, пробопідготовку. Вміст валових і рухомих (в амонійно-ацетанта витяжка $\mathrm{pH}=4,8$ ) форм $\mathrm{Zn}, \mathrm{Pb}, \mathrm{Cu}, \mathrm{Ni}, \mathrm{Cd}$ у грунтах та елементів у рослинному матеріалі визначали на атомно-абсорбційному спектрофотометрі С-115 (Україна). Коефіцієнт транслокації розраховували як співвідношення вмісту елемента в коренях рослин до вмісту його рухомих форм у грунті. Серед металів першого та другого класів небезпеки відмічаємо пропорційне збільшення їх умісту від умовного контролю до ділянок високого рівня забруднення. Визначено спадаючий ряд рухомих форм важких металів: на ділянках з високим та помірним рівнем забруднення $-\mathrm{Zn}>\mathrm{Pb}>\mathrm{Cu}>\mathrm{Ni}>\mathrm{Cd}$, на ділянках з незначним рівнем та умовним контролем $-\mathrm{Zn}>\mathrm{Ni}>\mathrm{Pb}>\mathrm{Cu}>\mathrm{Cd}$. Установлено, що наявність зв'язку між накопиченням важких металів у грунті та коренях рослин дозволяє використовувати Taraxacum officinale Wigg для здійснення біоіндикації.
\end{abstract}

Ключові слова: техногенне середовище, важкі метали, транслокаційні коефіцієнти, забруднення, стійкість рослин, біоіндикації, Taraxacum officinale Wigg.

Bcmyn. Едафотопи $є$ активними акцепторами більшості елементів i їх сполук, зокрема важких металів (BM) [2, 25, 28, 32]. Мікроелементи активно сорбуються та взаємодють із гумусовими сполуками, у результаті чого їх рухливість зменшується $[1,3,17]$. Визначення спроможності певних елементів до транслокації в системі «грунт- 
рослина» $\epsilon$ необхідною складовою моніторингових досліджень урболандшафтів [20, 21, 29].

У вегетавних органах рослин часто відмічають різну концентрацію ВM, що обумовлено властивостями самих мікроелементів та видоспецифічністю метаболічних процесів у рослин. Зокрема, вміст $\mathrm{Cd}$ у рослинах залежить від біологічних особливостей і наявності елементностатичних бар'єрів на кордоні «корінь-стебло» [8, 9, 23]. Коливання умісту $\mathrm{Cu}$ на різних грунтах та у кліматичних умовах зумовлює значну варіабельність його накопичення рослинами $[13,14,31]$. При вивченні особливостей надходження Zn у рослини був виявлений ген ZNT1, який відповідає за його транспорт [24]. Іони Рb стимулюють процеси пероксидного окиснення ліпідів, що підтверджується підвищенням вмісту ТБК-активних продуктів у вегетативних органах [15]. Вміст $\mathrm{Ni}$ у грунтах значною мірою залежить від забезпеченості елементом грунтоутворюючих порід. Найбільші концентрації $\mathrm{Ni}$, як правило, становлять до 3,0 мг/кг при варіаціях у різних видах рослин становить від 0,1-1,0 до 8,1 мг/кг [27].

Саме тому використання розповсюджених видів урбанофлори в біоіндикації дозволяе оцінювати рівень забруднення промислових агломерацій. Аналіз наукової літератури свідчить, що індикаторними видами техногенного забруднення можуть слугувати сільськогосподарські культури $[10,16,26]$; деревні рослини $[5,7,22,28]$; трав'янисті види $[5,14,33]$.

Мета дослідження - визначити рівень акумуляції важких металів в едафотопах м. Кривого Рогу та з'ясувати можливість використовувати Taraxacum officinale Wigg для здійснення біоіндикації довкілля в гірничо-металургійному регіоні.

Матеріал та методи дослідження. Об'єктом дослідження були грунти і корені Taraxacum officinale Wigg. Пробні ділянки закладалися в трьох адміністративних районах м. Кривий Ріг з різним рівнем надходження викидів від стаціонарних джерел забруднення в атмосферне повітря. За даними Головного управління статистики у Дніпропетровській області, територія Металургійного району міста характеризується найвищим рівнем промислових викидів $(102,4$ тис. т у 2013 році). У даному районі закладені пробні ділянки з високим рівнем забруднення в санітарно-захисній зоні 9-тої доменної печі ПАТ «АрселорМіттал Кривий Ріг» (ділянка 1, 4751'58.3”N 33²4'35.6”Е),

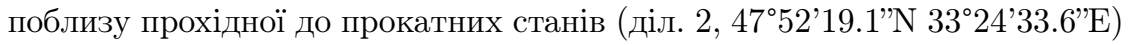
і прохідної № 1 підприємства (діл. 3, 4753’01.9” 33²3'10.5”Е) та вантажної прохідної ПрАТ «Криворізький суриковий завод» (діл. 4, 
$47^{\circ} 53$ '31.6”'N 3324'58.1'Е). У Покровському і Довгинцевському районах обсяги викидів 3,8 і 2,4 тис. т відповідно. У цих районах розташовані ділянки з помірним рівнем забруднення у санітарно-захисній зоні шахти Ювілейна ПрАТ «Суха Балка» (діл. 5, 4801'51.8”N 33²7'47.2”Е)

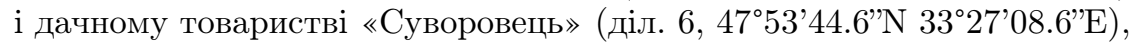
що межує із санітарно-захисною зоною ПрАТ «Криворізький суриковий завод». У Саксаганському районі, у якому найменші обсяги викидів до 640 т, закладені ділянки з незначним рівнем забруднення по

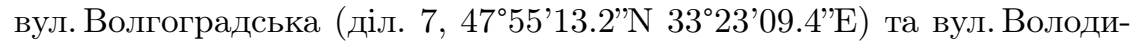

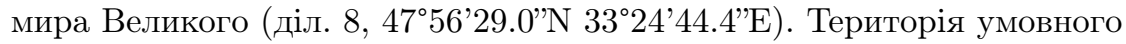
контролю розташована на відстані понад 50 км від промислових підприємств (діл. 9, 4808'48.8”N 3254'18.8'Е).

Відбір проб з шару грунту 0-10 см і коренів рослин проводили наприкінці вересня, а пробопідготовку здійснювали за загальноприйнятими методиками $[12,30]$. Вміст валових і рухомих (в амонійно-ацетанта витяжка $\mathrm{pH}=4,8)$ форм $\mathrm{Zn} ; \mathrm{Pb} ; \mathrm{Cu} ; \mathrm{Ni}$; $\mathrm{Cd}$ у грунтах та елементів у рослинному матеріалі визначали на атомно-абсорбційному спектрофотометрі C-115 (Україна). Коефіцієнт транслокації розраховували як співвідношення вмісту елемента у коренях рослин до вмісту його рухомих форм у грунті $[4,12]$.

Результати експерименту оброблені статистично: розраховували помилку середньої арифметичної, обчислювали критерій достовірності відмінностей між показниками варіантів (t-test). Різницю вважали достовірною за $\mathrm{P}<0,05$.

Резулътати та їх обговорення. Обговорюючи вміст рухомих форм важких металів у грунтах міста та їх відсоток до валової форми, необхідно відмітити, що отримані результати є статистично достовірними для всіх ділянок, окрім ділянки 5 із вмістом кадмію та ділянки 6 із вмістом нікелю (Табл. 1). Серед металів першого класу небезпеки відсотковий вміст валової форми Zn пропорційно зростає від $10,5 \%$ в умовному контролі до $55,1 \%$ для територій з високим вмістом забруднення. Вміст рухомої форми цинку закономірно підвищується на ділянках з високим рівнем забруднення від 5,5 до 16 разів порівнюючи із контролем. У цей діапазон потрапила ділянка 7 , де перевищення цинку становить понад 6 разів (Табл. 1). Серед інших металів першого класу не відмічено дисбалансу між пробними площадками за рівнями забруднення. Так, вміст $\mathrm{Pb}$, у порівнянні із контролем, збільшився від 3 до 8,5 разів на ділянках із помірним та незначним забрудненням та від 18 до 32 разів на ділянках із високим рівнем. Отримані результати вмісту кадмію дещо знижені у порівнянні із контролем на ділянках $5-8$, 
які розташовані в зонах з незначним та помірним рівнями забруднення, а на ділянках з високим рівнем зафіксоване перевищення від 6 до 47 разів (Табл. 1). Серед металів другого класу небезпеки на ділянках незначного та помірного рівнів забруднення відмічаємо збільшення ïx вмісту у порівнянні із контролем від 2 до 5 разів та на ділянках високого рівня забруднення від 6 до 36 разів (Табл. 1).

\section{Таблиця 1. Вміст рухомих форм важких металів у грунті Table 1 . The heavy metals mobile forms content in the soil}

\begin{tabular}{|c|c|c|c|c|c|c|}
\hline \multicolumn{2}{|r|}{$\begin{array}{c}\text { Пробні } \\
\text { площадки та } \\
\text { координати }\end{array}$} & $\mathrm{Ni}$ & $\mathrm{Cu}$ & $\mathrm{Zn}$ & $\mathrm{Pb}$ & $\mathrm{Cd}$ \\
\hline \multirow{2}{*}{1} & $47^{\circ} 51^{\prime} 58.3^{\prime \prime} \mathrm{N}$ & $10,93 \pm 0,05^{*}$ & $6,36 \pm 0,05^{*}$ & $39,49 \pm 1,42^{*}$ & $15,05 \pm 0,05^{*}$ & $2,52 \pm 0,15^{*}$ \\
\hline & $33^{\circ} 24^{\prime} 35.6^{\prime \prime} \mathrm{E}$ & $80,6 \%$ & $15,5 \%$ & $55,1 \%$ & $13,1 \%$ & $35,4 \%$ \\
\hline \multirow{2}{*}{2} & $47^{\circ} 52^{\prime} 19.1^{\prime \prime N}$ & $6,62 \pm 0,18^{*}$ & $18,01 \pm 0,55^{*}$ & $98,24 \pm 16,61^{*}$ & $19,88 \pm 0,24^{*}$ & $8,11 \pm 0,19^{*}$ \\
\hline & $33^{\circ} 24^{\prime} 33.6 \prime \mathrm{E}$ & $21,9 \%$ & $17,6 \%$ & $14,5 \%$ & $14,6 \%$ & $64,9 \%$ \\
\hline \multirow{2}{*}{3} & $47^{\circ} 53^{\prime} 31.6^{\prime \prime} \mathrm{N}$ & $8,39 \pm 0,22^{*}$ & $20,64 \pm 0,73^{*}$ & $63,92 \pm 0,49^{*}$ & $26,13 \pm 0,31^{*}$ & $12,17 \pm 0,20^{*}$ \\
\hline & $33^{\circ} 24^{\prime} 58.1^{\prime \prime} \mathrm{E}$ & $24,5 \%$ & $15,8 \%$ & $25,5 \%$ & $15,0 \%$ & $42,6 \%$ \\
\hline \multirow{2}{*}{4} & $47^{\circ} 53^{\prime} 01.9^{\prime \prime} \mathrm{N}$ & $6,87 \pm 0,02^{*}$ & $6,38 \pm 0,22^{*}$ & $34,01 \pm 2,67^{*}$ & $25,5 \pm 0,60^{*}$ & $1,65 \pm 0,16^{*}$ \\
\hline & $33^{\circ} 23^{\prime} 10.5^{\prime \prime} \mathrm{E}$ & $63,3 \%$ & $22,3 \%$ & $15,8 \%$ & $26,0 \%$ & $38,8 \%$ \\
\hline \multirow{2}{*}{5} & $48^{\circ} 01^{\prime} 51.8^{\prime \prime} \mathrm{N}$ & $6,82 \pm 0,32^{*}$ & $1,62 \pm 0,02^{*}$ & $33,23 \pm 0,38^{*}$ & $6,89 \pm 0,91^{*}$ & $0,35 \pm 0,01$ \\
\hline & $33^{\circ} 27^{\prime} 47.2^{\prime \prime} \mathrm{E}$ & $39,9 \%$ & $9,5 \%$ & $21,3 \%$ & $25,3 \%$ & $31,8 \%$ \\
\hline \multirow{2}{*}{6} & $47^{\circ} 53^{\prime} 44.6^{\prime \prime} \mathrm{N}$ & $2,29 \pm 0,11$ & $2,84 \pm 0,70^{*}$ & $20,58 \pm 2,67^{*}$ & $3,37 \pm 0,88^{*}$ & $0,23 \pm 0,17^{*}$ \\
\hline & $33^{\circ} 27^{\prime} 08.6^{\prime \prime} \mathrm{E}$ & $18,6 \%$ & $14,6 \%$ & $10,45 \%$ & $5,9 \%$ & $14,3 \%$ \\
\hline \multirow{2}{*}{7} & $47^{\circ} 56^{\prime} 29.0^{\prime \prime} \mathrm{N}$ & $4,34 \pm 0,17^{*}$ & $1,26 \pm 0,06^{*}$ & $16,66 \pm 0,90^{*}$ & $6,88 \pm 0,59^{*}$ & $0,15 \pm 0,01^{*}$ \\
\hline & $33^{\circ} 24^{\prime} 44.4^{\prime \prime} \mathrm{E}$ & $41,7 \%$ & $13,9 \%$ & $25,9 \%$ & $22,4 \%$ & $27,8 \%$ \\
\hline \multirow{2}{*}{8} & $47^{\circ} 55^{\prime} 13.2^{\prime \prime} \mathrm{N}$ & $4,58 \pm 0,08^{*}$ & $1,37 \pm 0,12^{*}$ & $40,32 \pm 3,36^{*}$ & $2,47 \pm 0,65^{*}$ & $0,17 \pm 0,01^{*}$ \\
\hline & $33^{\circ} 23^{\prime} 09.4^{\prime \prime} \mathrm{E}$ & $31,6 \%$ & $9,4 \%$ & $33,1 \%$ & $12,3 \%$ & $23,9 \%$ \\
\hline \multirow[t]{2}{*}{9} & $48^{\circ} 08^{\prime} 48.8^{\prime \prime} \mathrm{N}$ & $1,44 \pm 0,03$ & $0,56 \pm 0,06$ & $6,17 \pm 0,44$ & $0,82 \pm 0,04$ & $0,26 \pm 0,04$ \\
\hline & $32^{\circ} 54^{\prime} 18.8^{\prime \prime} \mathrm{E}$ & $18,7 \%$ & $6,1 \%$ & $10,5 \%$ & $5,3 \%$ & $33,8 \%$ \\
\hline
\end{tabular}

Примітка: чисельник - вміст рухомих форм ВМ в Ірунтах, мг/кг грунту; знаменник - відношення рухомих форм до валових, \%;

* - різниця достовірна з контролем $(\mathrm{P}<0,05) ;(\mathrm{M} \pm \mathrm{m}, \mathrm{n}=3)$

Серед відношень рухомих до валових форм важких металів спостерігаємо значні коливання та відсутність чіткої градації між ділянками різних рівнів забруднення (Табл. 1). Загальна техногенність досліджених рухомих форм важких металів для ділянок з високим та помірним рівнем забруднення утворює спадаючий ряд, який набуває такого вигляду: $\mathrm{Zn}>\mathrm{Pb}>\mathrm{Cu}>\mathrm{Ni}>\mathrm{Cd}$. 
Слід зазначити, що одночасно зафіксована незначна різниця в накопиченні кадмію та нікелю на ділянці 4. Для пробних ділянок незначного рівня та умовного контролю ряд накопичення важких металів виглядає наступним чином: $\mathrm{Zn}>\mathrm{Ni}>\mathrm{Pb}>\mathrm{Cu}>\mathrm{Cd}$. (Табл. 1).

Літературні дані свідчать, що збільшення значення $\mathrm{pH}$ та вмісту гумусу в грунтах супроводжується зниженням рухливості іонів важких металів, що істотним чином впливає на рівень концентрації важких металів як в едафотопах так і рослинному покриві. Така буферна властивість виступає потужним бар'єром, зокрема встановлено, що в інтервалі $\mathrm{pH}$ від 4 до 7,7 сорбційна здатність грунтів збільшується в 2-3 рази на кожну одиницю $\mathrm{pH}[11,28]$. У лабораторних дослідах підтверджено рівномірне зростання адсорбції грунтами кадмію при збільшенні $\mathrm{pH}$ грунтового розчину від 2 до 7 [33].

У ході наших попередніх досліджень встановлено, що середній вміст гумусу в едафотопах м. Кривий Ріг знаходиться на рівні $1,0-4,5 \%$, зокрема найбільша кількість органічної речовини виявлена в грунтах Металургійного району, який характеризується високим рівнем забруднення. Це можна пояснити активними вторинними сукцесійними процесами відновлення рослинного та, як наслідок, грунтового покривів. Показники як актуальної, так і обмінної кислотності коливаються від нейтрального $(6,8-7,2 \%)$ до середньолужної $(8,5-9,0 \%)[18,19]$. При тому, що лужну реакцію спостерігаємо на всіх ділянках з високим, а нейтральну на ділянках з помірним та незначним рівнями забруднення. Зважаючи на отримані результати вмісту різних форм важких металів та деяких буферних характеристик грунту, вважаємо доцільно розглядати транслокаційні коефіцієнти, зокрема на прикладі синантропного виду $T$. officinale, $з$ метою оцінити ступінь доступності мікроелементів у середовищі існування рослини та у подальшому використовувати показник як чутливий біоіндикатор їх вмісту.

Необхідно відмітити чітку закономірність збільшення концентрації нікелю елементу в 2 рази на площадках високого рівня. Виключенням у цьому списку є ділянка № 4, де помічена різниця більше ніж у 3 рази у порівнянні із контролем. Площадки незначного та помірного рівнів характеризуються тенденцією збільшення нікелю в 1,5 рази у порівнянні 3 контролем. Але на ділянці № 8 виявлено статистично достовірне зниження вмісту нікелю, що становить 2,25 $\pm 0,47$ мг/г (Табл. 2). На пробних площадках високого рівня забруднення зафіксовано перевищення купруму в коренях рослин у 6 разів, а на ділянках 5 та 8 до 15\%. Виключенням є ділянки 3 та 7 , де зафіксовано незначне зниження у порівнянні із контролем. Проте важливо зазначити, що ці 
дані є статистично недостовірними аналогічно і з результатами ділянки 6 , хоча на ній рівень накопичення вищий ніж в контролі (Табл. 2).

Таблиця 2. Вміст важких металів у корені Taraxacum officinale Wigg, мг/кг та значення коефіцієнту транслокації в системі «грунт-корінь»

Table 2. The heavy metals content in root of Taraxacum officinale Wigg, $\mathrm{mg} / \mathrm{kg}$ and a translocation factor value for a system "soil-root"

\begin{tabular}{|c|c|c|c|c|c|c|}
\hline \multicolumn{2}{|c|}{$\begin{array}{c}\text { Пробні } \\
\text { площадки та } \\
\text { координати }\end{array}$} & $\mathrm{Ni}$ & $\mathrm{Cu}$ & $\mathrm{Zn}$ & $\mathrm{Pb}$ & $\mathrm{Cd}$ \\
\hline 1 & $47^{\circ} 51^{\prime} 58.3^{\prime \prime} \mathrm{N}$ & $5,70 \pm 0,67^{*}$ & $2,49 \pm 0,06^{*}$ & $52,83 \pm 1,04^{*}$ & $3,14 \pm 0,22^{*}$ & $8,03 \pm 0,39 *$ \\
\hline & $33^{\circ} 24^{\prime} 35.6^{\prime \prime} \mathrm{E}$ & 1,92 & 2,55 & 0,75 & 4,80 & $0,31 \%$ \\
\hline \multirow[t]{2}{*}{2} & $47^{\circ} 52^{\prime} 19.1^{\prime \prime N}$ & $6,92 \pm 0,17^{*}$ & $2,59 \pm 0,06^{*}$ & $75,10 \pm 0.02^{*}$ & $4,87 \pm 0,55^{*}$ & $9,38 \pm 0,52^{*}$ \\
\hline & $33^{\circ} 24^{\prime} 33.6^{\prime \prime} \mathrm{E}$ & 1,04 & 6,94 & 2,15 & 4,08 & 0,86 \\
\hline \multirow{2}{*}{3} & $47^{\circ} 53^{\prime} 31.6^{\prime \prime} \mathrm{N}$ & $8,86 \pm 0,39^{*}$ & $2,92 \pm 0,50^{*}$ & $70,58 \pm 5,06^{*}$ & $4,81 \pm 0,33^{*}$ & $7,67 \pm 0,06^{*}$ \\
\hline & $33^{\circ} 24^{\prime} 58.1^{\prime \prime} \mathrm{E}$ & 0,95 & 7,08 & 0,91 & 5,43 & 1,59 \\
\hline \multirow{2}{*}{4} & $47^{\circ} 53^{\prime} 01.9^{\prime \prime} \mathrm{N}$ & $5,58 \pm 0,56^{*}$ & $0,44 \pm 0,06$ & $47,52 \pm 2,29 *$ & $3,62 \pm 0,22^{*}$ & $8,14 \pm 0,02^{*}$ \\
\hline & $33^{\circ} 23^{\prime} 10.5^{\prime \prime} \mathrm{E}$ & 1,23 & 14,35 & 0,72 & 7,00 & 0,20 \\
\hline \multirow[t]{2}{*}{5} & $48^{\circ} 01^{\prime} 51.8^{\prime \prime} \mathrm{N}$ & $3,89 \pm 0,32^{*}$ & $0,68 \pm 0,07^{*}$ & $13,67 \pm 0,68^{*}$ & $1,99 \pm 0,36$ & $2,31 \pm 0,22^{*}$ \\
\hline & $33^{\circ} 27^{\prime} 47.2^{\prime \prime} \mathrm{E}$ & 1,75 & 2,37 & 2,43 & 3,46 & 0,15 \\
\hline \multirow{2}{*}{6} & $47^{\circ} 53^{\prime} 44.6^{\prime \prime} \mathrm{N}$ & $4,45 \pm 0,29 *$ & $0,60 \pm 0,07$ & $12,02 \pm 1,47^{*}$ & $1,72 \pm 0,63$ & $2,75 \pm 0,12^{*}$ \\
\hline & $33^{\circ} 27^{\prime} 08.6^{\prime \prime} \mathrm{E}$ & 0,83 & 4,71 & 1,71 & 1,96 & 0,08 \\
\hline \multirow[t]{2}{*}{7} & $47^{\circ} 56^{\prime} 29.0^{\prime \prime} \mathrm{N}$ & $2,25 \pm 0,47^{*}$ & $0,63 \pm 0,06^{*}$ & $16,54 \pm 1,10^{*}$ & $1,48 \pm 0,14^{*}$ & $2,11 \pm 0,30^{*}$ \\
\hline & $33^{\circ} 24^{\prime} 44.4^{\prime \prime} \mathrm{E}$ & 1,93 & 2,02 & 1,01 & 4,65 & 0,07 \\
\hline \multirow{2}{*}{8} & $47^{\circ} 55^{\prime} 13.2^{\prime \prime} \mathrm{N}$ & $2,80 \pm 0,19$ & $0,46 \pm 0,04$ & $15,05 \pm 1,43^{*}$ & $2,08 \pm 0,16^{*}$ & $3,27 \pm 0,55^{*}$ \\
\hline & $33^{\circ} 23^{\prime} 09.4^{\prime \prime} \mathrm{E}$ & 1,64 & 2,97 & 2,68 & 1,19 & 0,05 \\
\hline \multirow{2}{*}{9} & $48^{\circ} 08^{\prime} 48.8^{\prime \prime} \mathrm{N}$ & $2,44 \pm 0,23$ & $0,49 \pm 0,02$ & $7,66 \pm 0,12$ & $1,34 \pm 0,07$ & $1,08 \pm 0,49$ \\
\hline & $32^{\circ} 54^{\prime} 18.8^{\prime \prime} \mathrm{E}$ & 0,59 & 1,14 & 0,81 & 0,61 & 0,24 \\
\hline
\end{tabular}

Примітка: чисельник - вміст BM у корені Taraxacum officinale Wigg, мг/кг; знаменник - коефіцієнт транслокації;

* - різниця достовірна з контролем $(\mathrm{P}<0,05) ;(\mathrm{M} \pm \mathrm{m}, \mathrm{n}=3)$

Абсолютним лідером з накопичення коренями є цинк. Спостерігаємо закономірне збільшення та чітку відмінність накопичення коренями на площадках різного рівня забруднення.

Установлено, що максимальне накопичення від 75,10 \pm 0,018 мг/г мало місце на ділянці № 2 до 47,52 $\pm 2,29$ біля вантажної прохідної цього ж підприємства, що перевищує контрольні значення у 6-10 
разів у порівнянні із контролем (Табл. 2). На площадках помірного та незначного рівнів забруднення спостерігаємо статистично закономірне збільшення накопичення металу у 2 рази. Причому, на ділянці № 8 цей показник знаходиться на рівні 16,54 $\pm 1,10$ мг/г, що більше на $3-4$ мг г від площадок із помірним рівнем навантаження.

Аналізуючи результати накопичення плюмбуму в коренях $T$. officinale, відмічаємо чітке розмежування між ділянками різного рівня забруднення. Максимальні значення зафіксовані на ділянці 2, що відповідають $4,87 \pm 0,55$ мг/г, а це співвідносне перевищенню у 4 рази порівнюючи із контролем. Мінімальні значення для площадок із високим рівнем установлені на ділянці 3 , які $є$ статистично достовірними і втричі перевищують дані контролю (Табл. 2). Експериментальні дані, отримані на ділянках помірного рівня мають незначне перевищення від контролю, але статистично недостовірні. Значення вмісту плюмбуму на ділянках незначного рівня забруднення мають перевищення у 1,5 рази від умовного контролю і відповідають $1,48 \pm 0,14 \mathrm{мг} / г$ та $2,08 \pm 0,16 \mathrm{мг} /$ г.

Подібно до нікелю відбувається активне накопичення коренями рослин і кадмію (Табл. 2). Градація накопичення на площадках із високим рівнем забруднення зафіксована в межах від 7,67 $\pm 0,06$ мг/г до $9,38 \pm 0,52$ мг/г, що становить збільшення у 8-9 разів порівняно із контролем (Табл. 2). Ділянки помірного рівня забруднення відмічаються статистично достовірним збільшенням накопичення металу від $2,31 \pm 0,02$ до $2,75 \pm 0,12$ мг/г. Ділянка незначного рівня забруднення характеризуються дещо відмінними показниками накопичень. Максимальне значення відповідає $3,27 \pm 0,55$ мг/г, що співвідносно перевищенню у 3 рази до контролю.

Отримані результати свідчать про значну акумуляцію іонів важких металів коренями кульбаби лікарської, що значною мірою пов'язано як із підвищеним вмістом зазначених елементів у пилових викидах підприємства, так і з певними особливостями процесів надходження іонів металів до рослин $[11,18]$. Наведені у таблиці 2 результати визначення вмісту у коренях рослин нікелю, купруму, цинку, плюмбуму та кадмію, свідчать про здатність T. officinale до їхньої акумуляції.

Логіку акумуляції мікроелементів можна відобразити у наступних спадаючих рядах, які диференційовані за ступенем забруднення територій (Табл. 3). На нашу думку, для характеристики стану забруднення природного середовища доцільно визначати не лише рухомі форми забруднюючих речовин у грунті, а й коефіцієнт їх переходу у системі «руннт-рослина». 
Таблиця 3. Ряди накопичення важких металів коренями Taraxacum officinale Wigg

Table 3. The heavy metals accumulation series by Taraxacum officinale Wigg roots

\begin{tabular}{|c|c|c|}
\hline \multicolumn{2}{|c|}{ Пробні площадки та координати } & Ряди накопичення важких металів \\
\hline 1 & $47^{\circ} 51^{\prime} 58.3^{\prime \prime} \mathrm{N} \quad 33^{\circ} 24^{\prime} 35.6^{\prime \prime} \mathrm{E}$ & $\mathrm{Zn}>\mathrm{Cd}>\mathrm{Ni}>\mathrm{Pb}>\mathrm{Cu}$ \\
\hline 2 & $47^{\circ} 52^{\prime} 19.1^{\prime \prime} \mathrm{N} \quad 33^{\circ} 24^{\prime} 33.6^{\prime \prime} \mathrm{E}$ & $\mathrm{Zn}>\mathrm{Cd}>\mathrm{Ni}>\mathrm{Pb}>\mathrm{Cu}$ \\
\hline 3 & $47^{\circ} 53^{\prime} 31.6^{\prime \prime} \mathrm{N} \quad 33^{\circ} 24^{\prime} 58.1^{\prime \prime} \mathrm{E}$ & $\mathrm{Zn}>\mathrm{Cd}>\mathrm{Cu}>\mathrm{Ni}>\mathrm{Pb}$ \\
\hline 4 & $47^{\circ} 53^{\prime} 01.9^{\prime \prime} \mathrm{N} \quad 33^{\circ} 23^{\prime} 10.5^{\prime \prime} \mathrm{E}$ & $\mathrm{Zn}>\mathrm{Ni}>\mathrm{Cd}>\mathrm{Pb}>\mathrm{Cu}$ \\
\hline 5 & $48^{\circ} 01^{\prime} 51.8^{\prime \prime} \mathrm{N} \quad 33^{\circ} 27^{\prime} 47.2^{\prime \prime} \mathrm{E}$ & $\mathrm{Zn}>\mathrm{Ni}>\mathrm{Cd}>\mathrm{Pb}>\mathrm{Cu}$ \\
\hline 6 & $47^{\circ} 53^{\prime} 44.6^{\prime \prime} \mathrm{N} \quad 33^{\circ} 27^{\prime} 08.6^{\prime \prime} \mathrm{E}$ & $\mathrm{Zn}>\mathrm{Ni}>\mathrm{Cd}>\mathrm{Pb}>\mathrm{Cu}$ \\
\hline 7 & $47^{\circ} 56 ' 29.0^{\prime \prime} \mathrm{N} \quad 33^{\circ} 24^{\prime} 44.4^{\prime \prime} \mathrm{E}$ & $\mathrm{Zn}>\mathrm{Ni}>\mathrm{Cd}>\mathrm{Pb}>\mathrm{Cu}$ \\
\hline 8 & $47^{\circ} 55^{\prime} 13.2^{\prime \prime} \mathrm{N} \quad 33^{\circ} 23^{\prime} 09.4^{\prime \prime} \mathrm{E}$ & $\mathrm{Zn}>\mathrm{Cd}>\mathrm{Ni}>\mathrm{Pb}>\mathrm{Cu}$ \\
\hline 9 & $48^{\circ} 08^{\prime} 48.8^{\prime \prime} \mathrm{N} \quad 32^{\circ} 54^{\prime} 18.8^{\prime \prime} \mathrm{E}$ & $\mathrm{Zn}>\mathrm{Ni}>\mathrm{Pb}>\mathrm{Cd}>\mathrm{Cu}$ \\
\hline
\end{tabular}

3 огляду на це були розраховані транслокаційні коефіцієнти для бар'єрного блоку «Ірунт-корені рослин». Міцний антиконцентраційний бар'єр як у контролі, так i за умов забруднення (коефіцієнт транслокації $<1,0)$, притаманний лише для кадмію. Але на ділянці 4 у рослин спостерігаємо мікроконцентаційний зв'язок (коефіцієнт транслокації $>1,0)$. Для більшості дослідних ділянок транслокація плюмбуму та купруму із грунту до коренів рослини вібдувається безбар'єрним способом. Лише в умовному контролі зафіксований антиконцентраційний бар'єр. Експериментальні результати дозволяють говорити про широке варіювання інтенсивності транслокації іонів цинку із грунту в корені. На ділянках з високим рівнем забруднення зафіксовано міцний бар'єр, окрім ділянки 2, де зафіксовано показник із значенням 2,15 (Табл. 2). Чіткого бар'єрного ефекту на територіях 3 помірним та 3 незначним рівнями забруднення не зафіксовано, а для ділянки 9 значення коефіцієнту дорівнює 0,81, що свідчить про наявність ефективного бар'єрного механізму (Табл. 2). Для нікелю інтенсивність транслокації із грунту до коренів практично однакова на всіх ділянках, окрім 9 та 6 , де спостерігається бар'єрний ефект.

Із результатами нашого дослідження узгоджуються дані щодо поглинання та транслокації Zn в умовах урбаносередовища м. Піза [6]. 
Разом із цим визначено, що найменше накопичується коренями рослин та безбар'єрно пересувається із грунту $\mathrm{Cu}$, а міцний антиконцентраційний бар'єр як у контролі, так і за умов забруднення є лише для $\mathrm{Cd}$. Оскільки накопичення кадмію в коренях займає не останнє місце, то варто припустити, що даний елемент потрапляє до рослин фоліарним шляхом.

Висновки. В умовах техногенного забруднення важкими металами екологічний фактор формування елементного складу рослин відіграє значну роль. За результатами виконаних досліджень можна дійти висновку про те, що процеси транслокації більшості важких металів до коренів T. officinale Wigg мають широке варіювання. Лідером накопичення як в грунті, так і в коренях рослин є цинк, який надходить до вегетативних органів безбар'єрним шляхом. Для кадмію зафіксовано наявність високого бар'єрного ефекту у системах «грунт-корінь».

Наявність зв'язку між накопиченням важких металів у грунті та коренях рослин дозволяє використовувати Taraxacum officinale Wigg для здійснення біоіндикації довкілля. Вважаємо за необхідне подальше та детальне дослідження адаптивних реакцій кульбаби лікарської з метою подальшого створення біоіндикаційних шкал.

\section{Reference}

1. Ali, H., Khan, E., \& Ilahi, I. (2019). Environmental chemistry and ecotoxicology of hazardous heavy metals: environmental persistence, toxicity, and bioaccumulation. Journal of Chemistry Volume, 2019, 1-14. https://doi.org/10.1155/2019/6730305

2. Aminiyan, M.M., Aminiyan, F.M., Mousavi, R., \& Heydariyan, A. (2016). Heavy metal pollution affected by human activities and different land-use in urban topsoil: A case study in Rafsanjan city, Kerman province, Iran. Eurasian Journal of Soil Science, 5 (2), 97. https://doi.org/10.18393/ejss.2016.2.097-104

3. Angelova, V., \& Ivanov, K. (2018). Heavy metal content in dandelion (Taraxacum officinale WEB.). Agricultural sciences, 10 (23), 55-62. https://doi.org/10.22620/agrisci.2018.23.008

4. Barman, S.C., Sahu, R.K., Bhargava, S.K., \& Chaterjee, C. (2000). Distribution of heavy metals in wheat, mustard and weed grains irrigated with industrial effluents. Bulletin of Environmental Contamination and Toxicology, 64 (4), 489-496. https://doi.org/10.1007/s001280000030 
5. Bessonova, V.P., \& Kryvoruchko, A.P. (2017). Changes in the structural indices of annual shoots of Quercus rubra under anthropogenic impact. Biosystems Diversity, $25(3)$, 191-196. https://doi.org/10.15421/011729

6. Bini, C., Maleci, L., Tani, C., \& Wahsha M. (2016). Preliminary observations on the metal tolerance and resilience capacity of Helichrysum italicum (Roth) G. Don growing on mine soils. EQA - Environmental quality, 21, 41-50 DOI: 10.6092/issn.2281-4485/6599.

7. Braun, J. (2020). Bioeconomy and its set of innovations for sustainability. Industrial Biotechnology, 16 (3), 142-143. https://doi.org/10.1089/ind.2020.29210.jvb

8. Dias, M. C., Correia, S., Serôdio, J., Silva, A. M. S., Freitas, H., \& Santos, C. (2018). Chlorophyll fluorescence and oxidative stress endpoints to discriminate olive cultivars tolerance to drought and heat episodes. Scientia Horticulturae, 231 (27), 31-35. https://doi.org/10.1016/j.scienta.2017.12.007

9. Fujimaki, S., Suzui, N., Ishioka, N. S., Kawachi, N., Ito, S., Chino, M., \& Nakamura, S. (2010). Tracing cadmium from culture to spikelet: noninvasive imaging and quantitative characterization of absorption, transport and accumulation of cadmium in an intact rice plant. Plant Physiology, 152, 1796-1806. https://doi.org/10.1104/pp.109.151035

10. Gill, S. S., Anjum, N. A., Gill, R., \& Tuteja N. (2016). Abiotic stress signaling in plants-an overview. In Abiotic Stress Response in Plants, First Edition. Tuteja M. (ed.) Gill S. S. (ed). (pp. 1-12). Wiley-VCH Verlag GmbH \& Ca.

11. Gryshko, V.M., Syshchykov, D. V., Piskova, O. M., \& Danilchuk, O. V. (2012). Vazhki metaly: nadkhodzhennia v grunty, trans lokatsiia u roslynakh ta ekolohichna bezpeka /Heavy metals: release into soils, translocation in plants and ecological hazard]. Donbass. (in Ukraine).

12. Gupta A., \& Balomajumder C. (2016). Simultaneous adsorption of $\mathrm{Cr}(\mathrm{VI})$ and phenol from binary mixture using iron incorporated rice husk: insight to multicomponent equilibrium isotherm. International Journal of Chemical Engineering, 2016. https://doi.org/10.1155/2016/7086761

13. Hall, R.D. (2018). Plant Metabolomics in a nutshell: potential and future challenges. Annual Plant Reviews book series, 41, https://doi.org/10.1002/9781119312994.apr0461 
14. Hänsch, R., \& Mendel, R. R. (2009). Physiological functions of mineral micronutrients $(\mathrm{Cu}, \mathrm{Zn}, \mathrm{Mn}, \mathrm{Fe}, \mathrm{Ni}, \mathrm{Mo}, \mathrm{B}, \mathrm{Cl})$. Current Opinion in Plant Biology, 12, 259-266. https://doi.org/10.1016/j.pbi.2009.05.006

15. Huang, L., Rad, S., Xu, L., Gui, L., Song, X., Li, Y., Wu, Z., \& Chen, Z. (2020) Heavy metals distribution, sources, and ecological risk assessment in huixian wetland, South China. Water, 12 (1), 431. https://doi.org/10.3390/w12020431

16. Juknys, R., Velička, R., Kanapickas, A., Kriaučiūnienè, Z., Masilionytè, L., Vagusevičienè, I., Pupalienè, R., Klepeckas, M., \& Sujetovienè, G. (2017). Projecting the impact of climate change on phenology of winter wheat in northern Lithuania. International Journal of Biometeorology, 61 (10), 1765-1775. https://doi.org/10.1007/s00484-017-1360-y

17. Komarova, I. O. (2013). Vmist vazhkykh metaliv u rekreatsiinykh ta promyslovykh zonakh Kryvorizhzhia [The content of mobile forms of heavy metals in recreation edaphotops and industrial areas of kryvorizhya]. Gruntoznavstvo [Soil Science], 14 (3-4), 35-42. (in Ukraine).

18. Komarova, I. O. (2015). Buferni vlastyvosti gruntiv yak pokaznyk zabrudnennia vazhkymy metalamy edafotopiv Kryvorizkoi urboekosystemy [Buffer properties as index of edaphotope heavy metal pollution of Kryvyi Rih urban ecosystems]. Ahroekolohichnyi zhurnal [Agroecological journal], 4, 34-44. (in Ukraine).

19. Komarova, I. O. (2015). Osoblyvosti funktsionuvannia roslynnoho orhanizmu v urbotekhnohennii ekosystemi (analiz stanu problemy) [Features of functioning of the plant organism in the urbatehnogennoy ekosistemme (the analysis of the problem)]. Pytannia bioindykatsii ta ekolohii [Problems of Bioindication and Ecology], 20 (2), 18-29. (in Ukraine).

20. Komarova, I. (2018). Taraxacum officinale as bioindicator of heavy metal accumulation in soil. Danish Scientific Journal, 8, 10-12. Retrieved from http://www.danish-journal.com/wp-content /uploads/2018/02/DSJ_8.pdf

21. Minkina, T.M., Mandzhieva, S.S., Chaplygin, V.A., Bauer, T. V., Burachevskaya, M.V., Nevidomskaya, D. G., \& Zamulina, I. V. (2017). Content and distribution of heavy metals in herbaceous plants under the effect of industrial aerosol emissions. Journal of Geochemical Exploration, 174, 113-120. https://doi.org/10.1016/j.gexplo.2016.05.011 
22. Mohamed, A. H., M'hamed, M., Fatma, M., \& Hichem, B. M. (2016). Air pollution mapping with bio-indicators in urban areas. In P. J. Sallis (ed.) Air quality - Measurement and modelling (pp. 163-183). In Tech. http://dx.doi.org/10.5772/65299

23. Nadgorska-Socha, A., Kandziora-Ciupa, M., Trzesicki, M., \& Barczyk, G. (2017). Air pollution tolerance index and heavy metal bioaccumulation in selected plant species from urban biotopes. Chemosphere, 183, 471-482. http://dx.doi.org/10.1016/j.chemosphere.2017.05.128

24. Peng, W., Li, X., Xio, S., \& Fan, W. (2018). Review of remediation technologies for sediments contaminated by heavy metals. Journal of Soils and Sediments volume, 18, 1701-1719. https://doi.org/ $10.1007 / \mathrm{s} 11368-018-1921-7$

25. Podolyak, A. G., \& Karpenko, A. F. (2019). Med v pahotnoy i lugovoy pochve Gomelschinyi [Copper in arable and meadow soils of Gomel region]. Ekolohichnyi visnyk Kryvorizhzhia [Ecological Bulletin of Kryvyi Rih District], 4, 56-66. https://doi.org/10.31812/eco-bulletinkrd.v4i0.2560 (in Ukrainian).

26. Radulescu, C., Iordache, S., Dunea, D., Stihi, C., \& Dulama, ID. (2015). Risks assessment of heavy metals on public health associated with atmospheric exposure to PM2.5 in urban area. Romanian Journal of Physics, 60 (7-8), 1171-1182.

27. Rascio, N., \& Navari-Izzo, F. (2011). Heavy metal hyperaccumulating plants: how and why do they do it? And what makes them so interesting? Plant science, 180 (2), 169-181. https://doi.org $10.1016 /$ j.plantsci.2010.08.016

28. Savosko, V. M. (2016). Tyazhelyie metallyi v pochvah Krivbassa [Heavy Metals in Soils at Kryvbas]. Dionat. (in Russian).

29. Stratu, A., Costica, N., \& Costica, M. (2016). Wooden species in the urban green areas and their role in improving the quality of the environment. Present Environment and Sustainable Development, 10 (2), 173-184. https://doi.org/10.1515/pesd-2016-0035

30. Tangahu, B. V., Kartika, A. A. G., \& Humaira, N. G. (2020). The lichen type identification as a bioindicator of air quality of sukolilo district in Surabaya, Indonesia. Technology Reports of Kansai University, 62 (03), 743-750. 
31. Tykhonenko, D.P., \& Dehtiarov, V.V. (2009). Praktykum z gruntoznavstva /Workshop on soil science]. Maidan. (in Ukraine).

32. Tytla, M., Widziewicz, K., \& Zielewicz, E. (2016). Heavy metals and its chemical speciation at different stages in sewage sludge of processing. Environmental Technology, 37 (7), 899-908. https://doi.org/10.1080/09593330.2015.1090482

33. Xiao, R., Wang, S., Li, R., Wang, J. J., \& Zhang, Z. (2017). Soil heavy metal contamination and health risks associated with artisanal gold mining in Tongguan, Shaanxi, China. Ecotoxicology and Environmental Safety, 141, 17-24. https://doi.org/10.1016/j.ecoenv.2017.03.002

34. Zhang, P., Liu, Y., Chen, X., Yang, Z., Zhu, M., \& Li, Y. (2016). Pollution resistance assessment of existing landscape plants on Beijing streets based on air pollution tolerance index method. Ecotoxicology and Environmental Safety, 132, 212-223. https://doi.org/10.1016/j.ecoenv.2016.06.003

\title{
THE EDAPHOTOPE'S CONDITION BIOINDICATIONS BY INDEX OF HEAVY METAL CONTENT ACCUMULATION AT VEGETATION BODIES (ON THE EXAMPLE OF Taraxacum officinale WIGG.)
}

\section{O. Komarova}

\author{
Kryvyi Rih State Pedagogical Unsversity, Kryvyi Rih, Ukraine
}

\begin{abstract}
Soil is an active acceptor for some elements, heavy metals in particular. Microelements are firmly sorbed and interact with soil humus layer. As a result, poorly soluble compounds are formed. Disruption of biogeochemical cycles leads to heavy metal accumulation in top layers of lithosphere and their uptake by plants with further migration in trophic chain. At the same time some plants are sensitive to soil contamination and can be used as bioindicators.

The objective of the paper is to assess protective attributes and specifics of translocation of different threat level elements of a synanthrope - Taraxacum officinale Wigg. The object of the study is the roots of Taraxacum officinale Wigg and the soils of plant habitat. Sampling sites were constructed in administrative regions of Kryvyi Rih city with different levels of emissions release into atmosphere from stationary pollution sources.

Soil sampling from $0-10 \mathrm{sm}$. layer and plants roots was taken in late September, sample preparation was performed according to established practices. The content of total and mobile (in ammonium acetate extraction $\mathrm{pH}=4,8$ ) forms of $\mathrm{Zn} ; \mathrm{Pb} ; \mathrm{Cu} ; \mathrm{Ni} ; \mathrm{Cd}$. in soils and elements in plant material was determined by atomic absorption spectrophotometer $\mathrm{C}-115$ (Ukraine). Translocation coefficient was calculated as ratio of element content in plants roots to its mobile forms content in soil. Statistical processing of experimental data was conducted according to standard methods of parametric statistics at $95 \%$ significance level.
\end{abstract}


Technogenicity of researched heavy metal mobile forms for the areas of high and moderate contamination forms a falling row which is ranked as follows: $\mathrm{Zn}>\mathrm{Pb}>\mathrm{Cu}>\mathrm{Ni}>\mathrm{Cd}$. But a nonsignificant difference was fixed in cadmium and nickel accumulation in the area № 4. For sampling sites of insignificant level and conditional control heavy metal accumulation row is ranked as follows: $\mathrm{Zn}>\mathrm{Ni}>\mathrm{Pb}>\mathrm{Cu}>\mathrm{Cd}$. The results of the determination of $\mathrm{Ni}, \mathrm{Cu}, \mathrm{Zn}, \mathrm{Pb}$ and $\mathrm{Cd}$ content in plants roots indicate that Taraxacum officinale Wigg is capable of their accumulation. $\mathrm{Zn}$ is an absolute leader in accumulation and bareerfree migration in the system "soil-plants roots". We were observing mobility decrease of one of the most dangerous elements - Cd. The interrelation between heavy metal accumulation in soil and plants roots enables to use Taraxacum officinale Wigg for applying phytoindication. We consider it essential to conduct further detailed research of Taraxacum officinale adaptive reactions with a view to further creating of bioindication scales.

Keywords: soil, plant, translocation coefficient, technogenic environment, heavy metals, contamination, Taraxacum officinale Wigg, bioindication.

\section{Citation as:}

Komarova, I. O. (2020). Bioindikatsiyi stanu edafotopu za pokaznikami akumulyatsiyi vazhkih metalIv vegetatsiynimi organami (na prikladi Taraxacum officinale Wigg.) [The edaphotope's condition

APA bioindications by index of heavy metal content accumulation at vegetation bodies (on the example of Taraxacum officinale Wigg.)]. Ekolohichnyi visnyk Kryvorizhzhia [Ecological Bulletin of Kryvyi Rih District], 5, 141-154. https://doi.org/10.31812/eco-bulletinkrd.v5i0.4360.

Комарова I. О. Біоіндикації стану едафотопу за показниками 8302:2015 акумуляції важких металів вегетаційними органами (на прикладі 2020. Вип. 5. С. $141-154$. 